\title{
SOME DEEP WELLS NEAR THE ATLANTIC COAST IN VIRGINIA AND THE CAROLINAS
}

\author{
By W. C. Mansfield
}

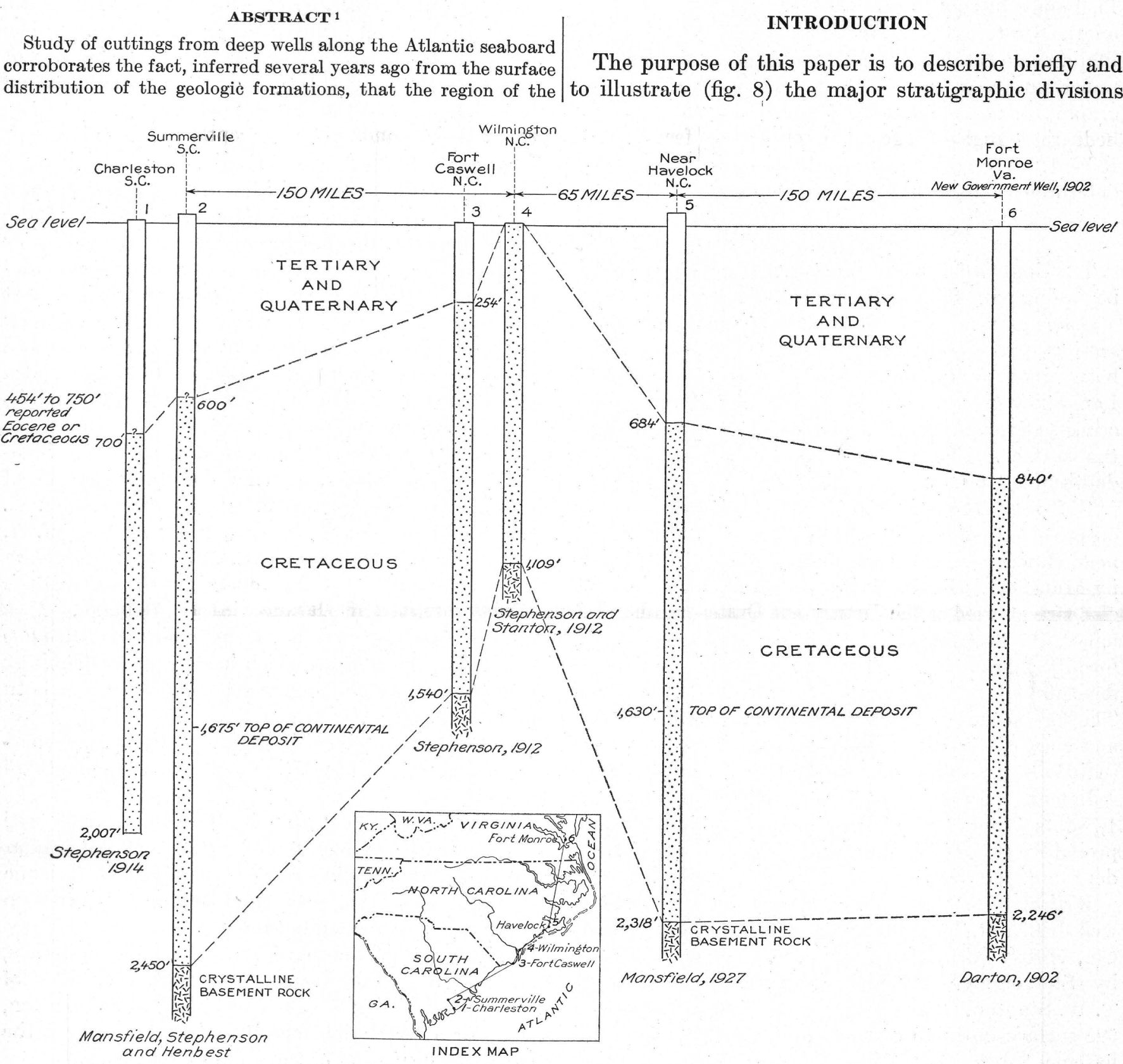

FIGURE 8.-Correlation of logs of deep wells near the Atlantic coast in Virginia and the Carolinas. Depths shown are measured from mouth of each well.

Cape Fear River in North Carolina is up-warped. Depths to /now recognized in six deep borings along the Atlantic crystalline bedrock in five wells are as follows: Fort Monroe, Va., 2,246 feet; near Havelock, N. C., 2,318 feet; Wilmington, N. C., 1,109 feet; Fort Caswell, N. C., 1,540 feet; Summerville, S. C., 2,450 feet. At Havelock and at Summerville the Upper Cretaceous-Eocene contact lies about 700 feet below the surface, but at Wilmington it is a few feet above sea level.

1 Mansfield, W. C., Washington Acad. Sci. Jour., vol. 19, no. 13, p. 287, 1929. Coastal Plain in Virginia and the Carolinas and to show the relations of these major divisions to each other.

Much of the information concerning these deep borings has already been published, but it seems desirable to give a diagrammatic summary of all of them. A 
complete $\log$ of the boring at Summerville, S. C., has not been published, but certain features concerning it have been briefly mentioned.

The Coastal Plain sedimentary deposits in Virginia and the Carolinas rest upon a basement composed mainly of crystalline rocks probably of pre-Cambrian age. These basement rocks are at the surface in the Piedmont Plateau, which borders the Coastal Plain on the west, but near the inner edge of the Coastal Plain, as at Halifax, Rocky Mount, and elsewhere, the upper surface of the basement dips beneath the topographic surface, and at the coast it lies deeply buried beneath sediments ranging in age from Cretaceous to Recent. The thickness of the sediments has been determined by the well borings.

\section{DETAILS OF THE WELLS}

The individual wells are briefly described below, beginning with the northernmost one.

Government well at Fort Monroe; Va.-A detailed section of the Government well at Fort Monroe has been given by Darton. ${ }^{2}$ The contact of the Eocene Pamunkey group with the underlying marine Cretaceous sediments is placed at a depth of 840 feet below the surface. The basement rock was reached at a depth of 2,246 feet.

Well near Havelock, N. C.-A complete record of an oil-prospecting well, the Great Lake well 2, drilled near Havelock, N. C., has been published in a paper by Mansfield. ${ }^{3}$ In this well the strata down to a depth of 684 feet were referred to the Tertiary and Quaternary. At that depth a stratigraphic break or unconformity marks the dividing line between the Eocene deposits above and the Cretaceous deposits below. The Cretaceous sediments are about 1,634 feet thick and comprise about 70 percent of the thickness of the sediments penetrated by the well. The nature of the sediments between approximate depths of 1,630 and 1,785 feet indicates a continental deposit. Granite, probably of pre-Cambrian age, was reached at a depth of 2,318 feet.

Well at Wilmington, N. C.-A complete record of a well drilled at the plant of the Clarendon Waterworks Co., Hilton Park, Wilmington, N. C., has been given by Stephenson. ${ }^{4}$ The fossils were determined by T. W. Stanton. The Cretaceous sediments range from the surface down to a depth of 1,109 feet, where the basement rock was reached.

Well at Fort Caswell, N.C.-A record of a well drilled at Fort Caswell, N. C., near the mouth of the Cape Fear River, has been given by Stephenson. ${ }^{5}$ The contact of the Tertiary and Quaternary with the

\footnotetext{
2 Darton, N. H., U. S. Geol. Survey Geol. Atlas, Norfolk folio (no. 80), columnarsection sheet, 1902.

3 Mansfield, W. C., Oil-prospecting well near Havelock, N. C.: North Carolina Dept. Cons. and Devel. Econ: Paper 58, 1927.

- Stephenson, L. W., The Cretaceous formations of North Carolina: North Carolina Geol. and Econ. Survey, vol. 3; pp. 163-166, 1912.

5 Idem, pp. 169-171
}

Cretaceous deposits was placed at a depth of 254 feet. The basement rock was reached at 1,540 feet. The fact that this well is nearer the coast than the well at Wilmington accounts for the greater depth to the basement rock. The Cretaceous sediments comprise about 80 percent of the deposits penetrated by the well.

Well at Summerville, S. C.-No complete log of the oil-prospecting well drilled at Summerville, S. C., has been published, but Cooke ${ }^{6}$ has given a brief log of this well. He assigns the strata penetrated between $37 \frac{1}{2}$ and 313 feet to the Eocene; between 313 and 1,580 feet to the Upper Cretaceous; and below this depth questionably to the Upper Triassic.

A study of the mollusks in the upper part of the well gave no positive evidence of the exact depth of the contact between the Eocene and younger deposits or the depth of the contact between the Eocene and Cretaceous. However, around the depth of 700 feet Stephenson recognized Cretaceous fossils belonging chiefly to the genera Belemnitella and Inoceramus, and L. G. Henbest identified a Cretaceous foraminifer at a depth of 640 feet. Henbest examined the Foraminifera to a depth of 708 feet, especially to determine the position of the Eocene-Cretaceous contact. He identified the following forms, which he states may be of either Cretaceous or Eocene age: Lenticularia cf. $L$. jonesi Sandidge (depth, 503-515 feet); Robulus cf. $R$. cultratus Montfort (depth 515-527 feet); Gyroidina sp. (depth 600-618 feet), close to $G$. alabamensis Sandidge of the Ripley formation of Alabama. At a depth of 640 feet and below he recognized Robulus navarroensis (Plummer), which he regards as definitely a Cretaceous species (range Taylor and Navarro, both Upper Cretaceous).

In the section given in figure 8 the CretaceousTertiary contact is tentatively placed at a depth of 600 feet.

The materials penetrated in the Summerville well between depths of $600(?)$ and 2,450 feet are similar to those in the Havelock well, in which no Triassic sediments were recognized, and are here referred in their entirety to the Cretaceous.

Beginning at a depth of 1,675 feet, the materials, consisting of reddish sandy clay with inclusions of coarse quartz grains, suggest, according to Stephenson, a delta or a terrestrial deposit and may represent the Tuscaloosa formation of the Upper Cretaceous.

A crystalline basement rock of a somewhat doubtful age was reached at a depth of 2,450 feet.

Well at Charleston, S. C.-A record of a well drilled at Charleston, S. C., has been published in a report by Stephenson. ${ }^{7}$ The strata between depths of 454 and 750 feet yielded no determinable fossils but are referred

${ }^{6}$ Cooke, C. W., Geology of the Coastal Plain of South Carolina: U. S. Geol. Survey Bull. 867, p. $177,1936$.

7 Stephenson, L. W., A deep well at Charleston, S. O.: U. S. Geol. Survey Prof. Paper 90-H, 1914. 
to the Upper Cretaceous or Eocene. At a depth of 750 feet Foraminefera were found which were regarded by J. A. Cushman as characteristic Cretaceous species.

The basement rock was not reached at 2,007 feet, the bottom of the well.

\section{GENERAL FEATURES}

Three of the wells-those near Havelock, at Wilmington, and at Summerville-lie about in a straight line trending $\mathrm{N} .56^{\circ} \mathrm{E}$., and this line is approximately parallel both to the coast and to the line marking the inner edge of the Coastal Plain. Wilmington is about 150 miles from Summerville and about 65 miles from the Great Lake well 2, near Havelock. The records of these wells show that the surface of the basement rock at Wilmington lies about 1,200 feet higher than it normally would be expected to lie on the assumption of a uniform dip of this surface, and this fact together with the surface distribution of the geologic formations seems to verify the opinion of Stephenson ${ }^{8}$ that the lower course of the Cape Fear River approximately marks the axis of a broad structural uplift, dating from the interval marked by the unconformity between the Cretaceous and Tertiary sediments, and that the uplifted position has been maintained without marked subsidence until the present time. It follows also that the Great Lake well 2, near Havelock, N. C., is

${ }^{8}$ Stephenson, L. W., Major features in the geology of the Atlantic and Gulf Coastal Pains: Washington Acad. Sci. Jour., vol. 16, no. 17, pl. 1, facing p. 466, 1926. located in a down-warped area, for the CretaceousEocene contact, which at Wilmington is a few feet above sea level, was reached in the well near Havelock at a depth of 684 feet, showing a relative sinking of the old Cretaceous-Eocene erosion surface amounting to nearly 700 feet. Summerville is also in a downwarped area, for there the Cretaceous-Eocene contact lies at a depth of about 600 feet. It is also interesting to note that the upper limit of the sediments referred to a continental deposit in the well near Havelock is 1,630 feet and in the well at Summerville 1,675 feet.

Stephenson ${ }^{9}$ shows a synclinal axis trending nearly northwest and crossing the Virginia and North Carolina line near the.coast. This axis is south of the location of the Fort Monroe well. The basement rock lies about 30 feet deeper in the well near Havelock than at Fort Monroe. The fact that Fort Monroe is a little nearer the inner edge of the Coastal Plain and farther from the edge of the Continental Shelf than the well near Havelock may account for this slight difference in the depths at which the basement rock was reached.

Evidence supporting the existence of a northwestsoutheast structural uplift near Wilmington has been recorded by MacCarthy. ${ }^{10}$

\footnotetext{
${ }^{9}$ Stephenson, L. W., Major marine transgressions and regressions and structural features of the Gulf Coastal Plain: Am. Jour. Sci., 5th ser., vol. 16, p. 294, fig. 12, 1928; Structural features of the Atlantic and Gulf Coastal Plain: Geol. Soc. America Bull., vol. 39, p. 839, fig. 1, 1928.

${ }^{10}$ MacCarthy, G. R., Magnetic anomalies and geologic structures of the Carolina
} Coastal Plain: Jour. Geology, vol. 44, no. 3, pp. 396-406, 1936. 